\title{
Physiological analysis of mutants of Saccharomyces cerevisiae impaired in sulphate assimilation
}

\author{
Dominique Thomas, ${ }^{*}$ Regine Barbey, Denise Henry and Yolande Surdin-Kerjan
}

Laboratoire d'Enzymologie du CNRS, 91198 Gif-sur-Yvette Cedex, France

(Received 5 May 1992; revised 19 June 1992; accepted 25 June 1992)

\begin{abstract}
The assimilation of sulphate in Saccharomyces cerevisiae, comprising the reduction of sulphate to sulphide and the incorporation of the sulphur atom into a four-carbon chain, requires the integrity of 13 different genes. To date, the functions of nine of these genes are still not clearly established. A set of strains, each bearing a mutation in one $M E T$ gene, was studied. Phenotypic studies and enzyme determinations showed that the products of at least five genes are needed for the synthesis of an enzymically active sulphite reductase. These genes are MET1, MET5, MET8, MET10 and MET20. Wild-type strains of S. cerevisiae can use organic metabolites such as homocysteine, cysteine, methionine and $S$-adenosylmethionine as sulphur sources. They are also able to use inorganic sulphur sources such as sulphate, sulphite, sulphide or thiosulphate. Here we show that both of the two sulphur atoms of thiosulphate are used by $\boldsymbol{S}$. cerevisiae. Thiosulphate is cleaved into sulphite and sulphide prior to utilization by the sulphate assimilation pathway, as the metabolism of one sulphur atom from thiosulphate requires the presence of an active sulphite reductase.
\end{abstract}

\section{Introduction}

In the yeast Saccharomyces cerevisiae, the assimilation of sulphate calls into play a set of five enzymic reactions, in addition to its uptake (Fig. 1). Sulphate reduction requires first an initial 'activation' to phosphosulphate compounds. As in Escherichia coli and Salmonella typhimurium, this activation is a two-step process in S. cerevisiae: ATP sulphurylase (encoded by the MET3 gene; Cherest et al., 1987) first catalyses the reaction of ATP and sulphate to give adenosine 5'-phosphosulphate (APS); then APS kinase (encoded by the MET14 gene, Korch et al., 1991) carries out a phosphorylation step that leads to the formation of 3'-phosphoadenosine 5'phosphosulphate (PAPS). The reduction of the sulphur atom is then achieved through two enzymic reactions. The first one, catalysed by PAPS reductase (encoded by the MET16 gene, Thomas et al., 1990) yields sulphite. Recent results (Thomas et al., 1990) have given new support to the first hypothesis of Tsang \& Schiff (1976) which involves the transfer of the sulphonyl moiety of PAPS to a thiol acceptor, presumably as a bound $\mathrm{S}_{-} \mathrm{SO}_{3}^{-}$ form. Then, sulphite reductase, a complex enzyme

\footnotetext{
* Author for correspondence. Tel. 1698234 64; fax 169823129.

Abbreviations: APS, adenosine 5'-phosphosulphate; PAPS, 3'phosphoadenosine $5^{\prime}$-phosphosulphate.
}

containing both a sirohaem and an iron-sulphur cluster, carries out the six-electron reduction of sulphite to sulphide. It is now clear that in yeast, sulphide is incorporated into a four-carbon chain yielding homocysteine (Cherest \& Surdin-Kerjan, 1992). Homocysteine synthase, which catalyses the synthesis of homocysteine from $O$-acetylhomoserine and sulphide, is encoded by the MET25 gene (Kerjan et al., 1986; Fig. 1).

In $S$. cerevisiae, methionine and cysteine both derive their sulphur from homocysteine while, in eubacteria, the sulphur atom of methionine is derived from cysteine (Cohen \& Saint Girons, 1987). Furthermore, eubacteria like $E$. coli cannot use methionine as sole sulphur source since they do not possess cystathionine $\beta$-synthase and $\gamma$ cystathionase activities. By contrast, the presence of the two trans-sulphuration pathways in $S$. cerevisiae allows it to use both methionine and cysteine as effective sulphur sources.

In addition to the genes MET3, MET14, MET16 and $M E T 25$ cited above, the products of nine other genes, MET1, MET4, MET5, MET8, MET10, MET18, $M E T 19, M E T 20$ and $M E T 22$, have been implicated in sulphate assimilation in yeast without their functions being clearly established (Masselot \& de RobichonSzulmajster, 1975). Recently, the roles of two of these genes were deciphered: MET4 was shown to encode the transcriptional activator of this pathway (Thomas et al., 


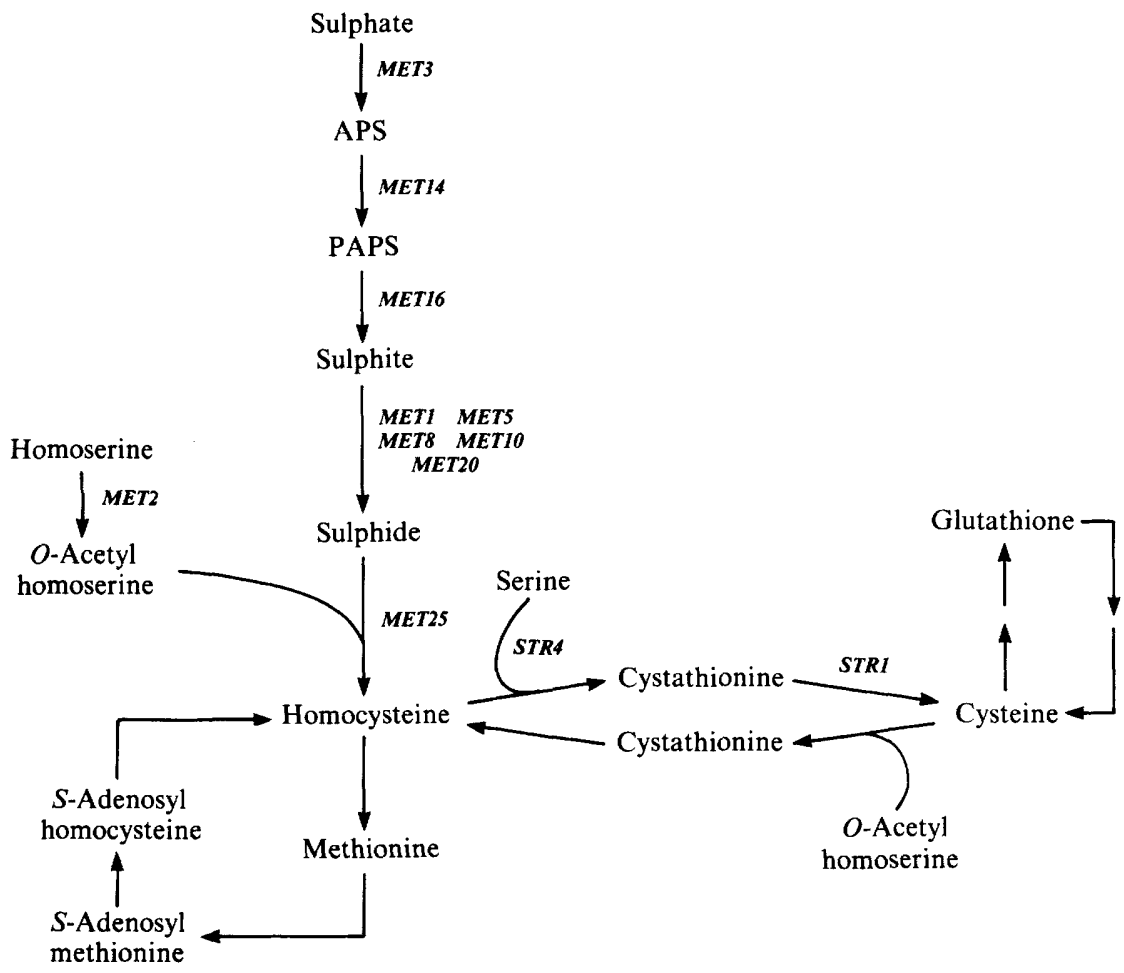

Fig. 1. Metabolism of sulphur amino acids in $S$. cerevisiae.

1992) while, unexpectedly, MET19 was proved to be the structural gene of yeast glucose-6-phosphate dehydrogenase (Thomas et al., 1991). The reasons why mutation or inactivation of the gene encoding the first enzyme of the pentose phosphate pathway leads to methionine auxotrophy are not yet understood.

The present work aims to clarify both phenotypic and enzymic characteristics of strains mutated in those genes involved in sulphate assimilation, the functions of which are still unknown.

\section{Methods}

Strains. The $S$. cerevisiae strains used are listed in Table 1. They are all derived from the parental strain CC359-OL2.

Media. YPG, YNBG and the sulphur-free medium B were as described in Cherest \& Surdin-Kerjan (1992). Cells grown in complete YPG medium were centrifuged and washed twice before being used to inoculate B or YNBG medium. The BIG-YPG medium was modified from Rikkerrink et al. (1988). It contained (w/v): $1 \%$ glucose, $1 \% \beta$ alanine, $0.25 \%$ yeast extract, $1 \%$ peptone, $0.1 \%$ bismuth ammonium citrate and $0.3 \%$ sulphite. With thiosulphate, BIG-YNB medium was used. It contained $1 \%$ glucose, $0.7 \%$ Yeast Nitrogen Base (Difco), $0.1 \%$ bismuth ammonium citrate and $50 \mathrm{~mm}$-thiosulphate, and was supplemented to meet the auxotrophic requirements of the strains. The bismuth-containing media were filter-sterilized.

Cell growth and preparation of cell-free extracts. For enzyme determinations, cells were grown in YNBG medium supplemented to
Table 1. Strains used

\begin{tabular}{lll}
\hline \hline \multicolumn{1}{c}{ Strain } & \multicolumn{1}{c}{ Genotype } & \multicolumn{1}{c}{ Source* } \\
\hline CC359-OL2 & MAT $\alpha$ his3 leu2 ura3 & Cherest et al. (1985) \\
CC346-3B & MATa ura3 met3 & H. Cherest \\
CC366-9C & MATa his3 leu2 ura3 met14 & H. Cherest \\
CC362-2A & MATa leu2 ura3 met 16 & Thomas et al. (1990) \\
C112 & MAT $\alpha$ his3 ura3 met25::HIS3 & Thomas et al. (1989) \\
CC469-13 & MAT $\alpha$ ura3 met1 & H. Cherest \\
CC361-1B & MAT $\alpha$ ura3 met5 & H. Cherest \\
CC496-43 & MAT $\alpha$ his3 ura3 met8 & Cherest et al. (1990) \\
CC501-2 & MAT $\alpha$ leu2 ura3 met10 & H. Cherest \\
CC363-20B & MATa leu2 ura3 met18 & H. Cherest \\
CC370-8C & MAT $\alpha$ ura3 met20 & H. Cherest \\
CC471-1D & MATa leu2 ura3 met4 & Thomas et al. (1992) \\
CC364-18C & MAT $\alpha$ his3 ura3 met22 & H. Cherest \\
\hline \hline
\end{tabular}

*H. Cherest, Laboratoire d'Enzymologie CNRS, Gif-sur-Yvette, France.

meet the auxotrophic requirements of the strains. For homocysteine synthase and ATP sulphurylase determinations, cells from $50 \mathrm{ml}$ cultures were collected by centrifugation, then washed and resuspended in $500 \mu \mathrm{l}$ of buffer A $(100 \mathrm{~mm}$-Tris/ $/ \mathrm{HCl}, \mathrm{pH} 7.5,0.1 \mathrm{~mm}$ EDTA, $10 \%$, w/v, glycerol, $1 \mathrm{mM}$-phenylmethylsulphonyl fluoride). Glass beads ( $500 \mu 1,0.45 \mathrm{~mm}$ diam.) were added and the extraction was performed as described in Thomas et al. (1989). The extract was dialysed for $16 \mathrm{~h}$ against $20 \mathrm{mM}-\mathrm{Tr}$ is $/ \mathrm{HCl}, \mathrm{pH} 7.5$, containing $0.1 \mathrm{mM}-$ EDTA and $10 \%$ glycerol. For PAPS reductase and sulphite reductase assays, cells from $200 \mathrm{ml}$ cultures were collected by centrifugation, then washed and suspended in $800 \mu \mathrm{l}$ of buffer A containing $1 \mathrm{~mm}-2$ mercaptoethanol. The cell suspension was separated into two micro- 
centrifuge tubes and $500 \mu \mathrm{l}$ of glass beads was added to each tube. The extraction was performed also as described in Thomas et al. (1989). Sulphite reductase was assayed on the crude extracts and PAPS reductase was assayed after dialysis (see below).

Enzyme assays. Homocysteine synthase and ATP sulphurylase were assayed as described in Thomas et al. (1992). Sulphite reductase was assayed by the method of de Vito \& Dreyfuss (1964) and the sulphide formed was estimated by the method of Siegel (1965). Four protein concentrations were assayed for each extract and were incubated for $10 \mathrm{~min}$ at $37^{\circ} \mathrm{C}$ in the assay medium prior to addition of the substrate (sulphite). As noted in the text, an improved assay for PAPS reductase activity was used: extracts were first dialysed at $4{ }^{\circ} \mathrm{C}$ for $4 \mathrm{~h}$ against four changes of $20 \mathrm{~mm}$-Tris/ $\mathrm{HCl}, \mathrm{pH} 7.5$ containing $1 \mathrm{mM}-2$-mercaptoethanol, $0.1 \mathrm{~mm}$-EDTA, $5 \mathrm{~mm}$-dithiothreitol and $10 \%$ glycerol. Four protein concentrations were used for each extract. The assay medium contained: $50 \mathrm{~mm}$-Tris/ $\mathrm{HCl} \mathrm{pH} \mathrm{7.5,} 5 \mathrm{~mm}$-dithiothreitol and 20,30, 40 and $50 \mu \mathrm{l}$ of cell-free extract in a final volume of $90 \mu \mathrm{l}$. After a preincubation at $37^{\circ} \mathrm{C}$ for $10 \mathrm{~min}, 10 \mu \mathrm{l}$ of a $5 \mathrm{~mm}$ solution of PAPS was added and the incubation was continued for $60 \mathrm{~min}$ at $37^{\circ} \mathrm{C}$. In this reaction, endogenous thioredoxin is reduced in a purely chemical fashion by dithiothreitol (Schwenn et al., 1988). For each assay, a control without PAPS was run. The sulphite formed in the reaction was estimated by the method of Grant (1947). A slight activation of PAPS reductase activity was measured at higher protein concentrations.

Protein concentrations were estimated by the Lowry method.

Intracellular sulphite concentration. Strains to be tested were grown in $10 \mathrm{ml}$ of minimal medium YNBG supplemented according to the auxotrophic requirements of the different strains. When the cellular concentration was about $10^{7}$ cells $\mathrm{ml}^{-1}$, cells were collected by centrifugation and suspended in $250 \mu \mathrm{l}$ of water. Chloroform $(15 \mu 1)$ and $0.1 \% \operatorname{SDS}(5 \mu \mathrm{l})$ were added to the cell suspension. Vortexing at maximum speed for $30 \mathrm{~s}$ followed by a $5 \mathrm{~min}$ incubation at $30^{\circ} \mathrm{C}$ released soluble metabolites from the cells. The permeabilized cells were removed by centrifugation and the sulphite contained in the supernatant was estimated on 25 and $50 \mu \mathrm{l}$ samples by the method of Grant (1947).

Reproducibility. Except where otherwise stated, the figures given in the Tables are mean values from at least two experiments. In each experiment, the deviation from this mean value was at most $10 \%$.

\section{Results}

Growth rate of methionine auxotrophic strains on different sulphur sources

The phenotypic study of strains mutated in genes $M E T 1$, MET5, MET8, MET10 MET18, MET20 and MET22 was initiated by measuring the growth rates of each mutant in the presence of various inorganic and organic sulphur sources. The sulphur compounds tested were added to the sulphur-free medium B. Strains impaired in known functions as well as the parental strain were used as controls. As expected, organic sulphur sources (i.e. homocysteine, cysteine, methionine and $S$-adenosylmethionine) satisfied the sulphur requirement of all mutants (Table 2). In the case of inorganic sulphur sources, sulphate supported the growth of the wild-type

\section{Table 2. Growth of methionine auxotrophic mutants on different sulphur sources}

The mean generation time was calculated from growth curves. One growth-curve experiment was performed for each strain in each medium. -, No growth; + , growth for at least five generations.

\begin{tabular}{|c|c|c|c|c|c|c|c|c|}
\hline \multirow[b]{3}{*}{ Strain } & \multirow{3}{*}{$\begin{array}{l}\text { Relevant } \\
\text { genotype }\end{array}$} & \multicolumn{7}{|c|}{ Mean generation time $(\mathrm{h})$} \\
\hline & & \multicolumn{7}{|c|}{ Sulphur source:* } \\
\hline & & $\mathrm{SO}_{4}^{2-}$ & $\mathrm{SO}_{3}^{2-}$ & $\mathbf{S}^{2-}$ & $\mathrm{HC}$ & Met & Cys & SAM \\
\hline CC359-OL2 & - & $3 \cdot 5$ & $3 \cdot 5$ & + & 3.5 & $3 \cdot 0$ & $4 \cdot 5$ & $3 \cdot 0$ \\
\hline CC $346-3 B$ & met3 & - & 3 & + & 3 & $2 \cdot 75$ & $5 \cdot 0$ & $3 \cdot 5$ \\
\hline CC $366-9 \mathrm{C}$ & met14 & - & 4.75 & + & $4 \cdot 0$ & $4 \cdot 0$ & $3 \cdot 5$ & $3 \cdot 0$ \\
\hline CC $362-2 A$ & met 16 & - & $5 \cdot 0$ & + & $5 \cdot 5$ & $5 \cdot 0$ & $5 \cdot 0$ & $3 \cdot 5$ \\
\hline CC365-1A & met 25 & - & - & - & 3.0 & 3.0 & $7 \cdot 5$ & $3 \cdot 5$ \\
\hline CC469-13 & met1 & - & - & + & 3.0 & $3 \cdot 0$ & 3.5 & $3 \cdot 0$ \\
\hline CC361-1B & met 5 & - & - & + & $3 \cdot 5$ & $2 \cdot 5$ & 7.5 & 3.0 \\
\hline CC469-43 & met8 & - & - & + & $3 \cdot 0$ & $3 \cdot 5$ & $4 \cdot 5$ & $4 \cdot 0$ \\
\hline CC501-2 & met 10 & - & - & + & $3 \cdot 5$ & 3.0 & $3 \cdot 0$ & 3.0 \\
\hline CC363-7A & met 18 & - & - & + & 3.0 & $3 \cdot 0$ & 6.5 & $3 \cdot 5$ \\
\hline CC $370-8 \mathrm{C}$ & met 20 & - & - & + & $4 \cdot 0$ & $3 \cdot 5$ & $5 \cdot 5$ & $2 \cdot 5$ \\
\hline CC471-1D & met4 & - & - & - & $2 \cdot 5$ & $3 \cdot 0$ & $6 \cdot 0$ & 2.5 \\
\hline CC364-18C & met 22 & - & - & - & $4 \cdot 5$ & $3 \cdot 0$ & $5 \cdot 5$ & $5 \cdot 5$ \\
\hline
\end{tabular}

* The different sulphur sources, added to sulphur-free B medium, were: $\mathrm{SO}_{4}^{2-}$, sulphate (0.5 mM); $\mathrm{SO}_{3}^{2-}$, sulphite (0.5 mM); $\mathrm{S}^{2-}$, sulphide $(0.5 \mathrm{mM}) ; \mathrm{HC}$, DL-homocysteine $(0.2 \mathrm{mM})$; Met, L-methionine $(0.1 \mathrm{mM})$; Cys, L-cysteine ( $0.5 \mathrm{mM}) ; \mathrm{SAM}, S$-adenosylmethionine $(0.05 \mathrm{~mm})$

strain only, while sulphite satisfied the sulphur requirement of the met 3 , met 14 and met 16 mutants. These results are in accord with the functions assigned to these genes since their products catalyse the three steps preceding sulphite synthesis. Growth on sulphide was poor, even for wild-type strains, and did not allow the determination of a precise mean generation time. However, significant growth (for at least five generations) was observed in the case of the met 1 , met 5 , met 8, met 10 , met 18 and met 20 mutants and, as expected, for the met3, met 14 amd met 16 mutants. By contrast the met4, met 22 and met 25 mutants were absolutely unable to divide in the presence of sulphide as sulphur source.

\section{Intracellular sulphite concentration in different mutants}

Study of the gene MET16 has revealed that it encodes PAPS reductase. This enzyme has been shown to be homodimeric (Schwenn et al., 1988). Northern blot experiments revealed that METI6 was transcribed in met 1 and met 8 mutants although no PAPS reductase activity was measured in cell-free extracts of these strains (Thomas et al., 1990). To establish if this absence of activity in vitro reflected the in vivo situation, an assay (described in Methods) that allows determination of the intracellular concentration of sulphite in strains grown in 
Table 3. Intracellular sulphite concentration in different methionine auxotrophs

Each figure represents the mean value from at least two independent experiments. The deviation from this mean value was at most $10 \%$. , Below detection limit.

\begin{tabular}{llc}
\hline \hline Strain & $\begin{array}{c}\text { Relevant } \\
\text { genotype }\end{array}$ & $\begin{array}{c}\text { Intracellular sulphite } \\
\text { concentration [nmol sulphite } \\
(\mathrm{mg} \mathrm{dry} \mathrm{wt)})^{-1} \text { ] }\end{array}$ \\
\hline CC359-OL2 & - & - \\
CC371-1D & met3 & - \\
CC366-9C & met14 & - \\
CC362-2A & met16 & - \\
C112 & met25 & - \\
CC471-1D & met4 & - \\
CC364-18C & met22 & - \\
CC469-13 & met1 & 73 \\
CC361-1B & met5 & 26 \\
CC469-43 & met8 & 83 \\
CC501-2 & met 10 & 71 \\
CC363-7A & met18 & 34 \\
CC370-8C & met20 & 25 \\
\hline \hline
\end{tabular}

a sulphate-containing medium was devised. Analysis of the results (Table 3) showed that sulphite is not accumulated in three classes of strains: (i) wild-type strains that convert sulphite into sulphide through the metabolic route to sulphur amino acids; (ii) strains that are impaired in an enzyme step situated upstream of sulphite formation, as is the case in strains mutated in genes MET3, MET14 and MET16; and (iii) three other mutants namely the met4 mutant impaired in the transcriptional activation of all genes implicated in sulphate reduction, the met 25 mutant that accumulates sulphide as expected (see below) and the met 22 mutant.

In contrast, met 1, met 5 , met 8, met 10, met 18 and met 20 mutants accumulated sulphite, suggesting that all the corresponding mutations lead to an enzymically inactive sulphite reductase. This experiment also reveals that the metl and met8 mutations do not impair the PAPS reductase activity that is required for sulphite formation.

\section{Reduction of sulphite in vivo}

In order to establish that the accumulation of sulphite measured in the met 1 , met 5 , met 8 , met 10 , met 18 and met 20 mutants results from a defect in sulphide formation, we performed a complementary test by plating these mutants on sulphite-containing BIG-YPG medium plates. This medium allowed the direct visualization of the sulphide formed in vivo by its precipitation into brown bismuth sulphide. As can be seen in Fig. 2(a), met 1, met 5 , met 8 , met 10 , and met 20 mutants were white when grown on this medium, showing that they do not transform sulphite into sulphide. However, the met3, met16, met25, met4 and met22 mutants, as well as the parental strain, were brown when grown on this medium, showing that they are able to reduce sulphite to sulphide. These results are in agreement with the sulphite accumulation studies. As expected, the met25-disrupted strain turned dark brown due to its deficiency in sulphide incorporation. Unexpectedly, the met 18 mutant was pale brown in this test, although we found that it accumulated sulphite (Table 3).

\section{Enzyme activities in vitro}

The results described above for the metl and met 8 mutations conflict with two preceding papers (Masselot \& Surdin-Kerjan, 1977; Thomas et al., 1990) that reported a lack of PAPS reductase activity in cell-free extracts from met 1 and met 8 mutated strains. We modified our procedure for the PAPS reductase assay (see Methods). Using this assay, we detected a measurable PAPS reductase activity in cell-free extracts from all strains except met 16 and met 4 mutants (Table 4). We also determined the ATP sulphurylase, sulphite reductase and homocysteine synthase activities in all the mutated strains, and found that met 1 , met5, met 8 , met 10 , and met 20 mutants were devoid of detectable sulphite reductase activity, confirming the results of the physiological tests reported above, as well as those previously reported (Masselot \& Surdin-Kerjan, 1977). As expected, the met 3 mutant lacked ATP sulphurylase activity and the met 25 mutant was devoid of homocysteine synthase activity. The met 18 mutant showed no sulphite reductase activity in vitro, in accord with the accumulation of sulphite by this mutant but not with its low formation of sulphide in the bismuth test. The met 22 mutant exhibited all enzyme activities. The inability of the met 22 mutant to use sulphate, sulphite and sulphur as sulphur sources thus cannot be explained by an impairment in some enzyme activity involved in sulphate reduction.

\section{Utilization of thiosulphate}

To try to understand how $S$. cerevisiae uses thiosulphate, we tested the met mutants on thiosulphate-containing BIG-YNB medium. In this case (Fig. $2 b$ ), all the strains turned brown, the met25-disrupted strain becoming almost black. This clearly shows that sulphite reductase activity is not required for the synthesis of sulphide from thiosulphate, as strains devoid of sulphite reductase activity are able to carry out this reaction. In other words, yeast contains an enzyme system capable of cleaving thiosulphate to yield sulphide, and the met 25 and met4 mutants can cleave thiosulphate to yield sulphide. Nevertheless, they are unable to use thiosulphate as a sulphur source (Table 5) 

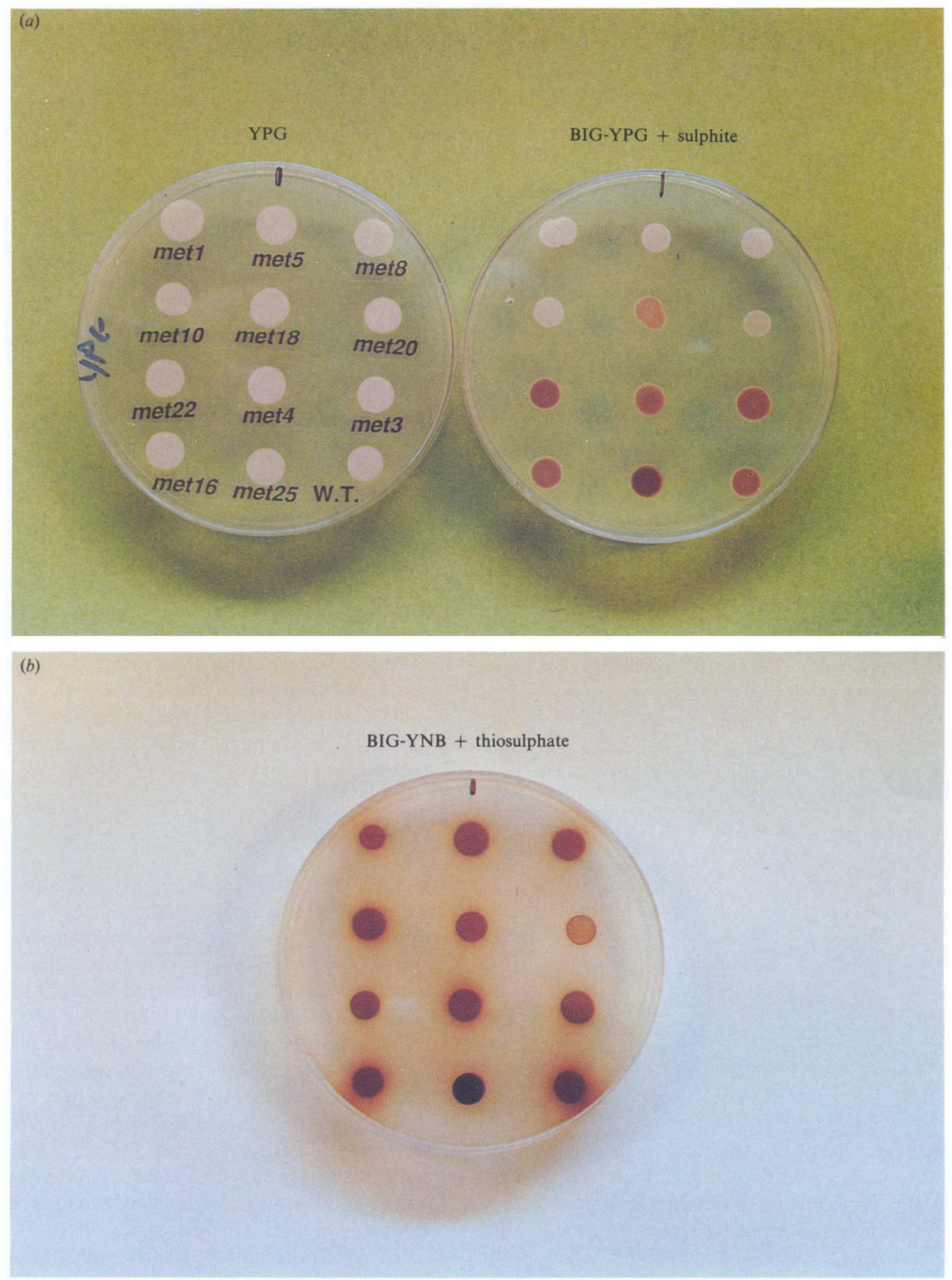

Fig. 2. (a) Physiological characterization of sulphide formation from sulphite in different met mutants. The different strains were grown on a minimal medium containing all factors necessary to meet growth requirements. They were then tested on YPG (left) and BIG-YPG medium containing sulphite (right). (b) Physiological characterization of sulphide formation from thiosulphate in different met mutants. Strains were tested on BIG-YNB medium containing all factors necessary to meet growth requirements of the strains, together with $50 \mathrm{~mm}$-thiosulphate. The strains were tested in the same order as in (a). 
Table 4. Enzyme activities in different methionine auxotrophs

Each figure represents the mean value from at least two independent experiments. -, Below detection limit.

\begin{tabular}{|c|c|c|c|c|c|}
\hline \multirow[b]{2}{*}{ Strain } & \multirow[b]{2}{*}{$\begin{array}{l}\text { Relevant } \\
\text { genotype }\end{array}$} & \multicolumn{4}{|c|}{$\begin{array}{c}\text { Enzyme activity } \\
\left.\text { [nmol substrate transformed } \text { min }^{-1}(\mathrm{mg} \text { protein })^{-1}\right]\end{array}$} \\
\hline & & $\begin{array}{c}\text { ATP } \\
\text { sulphurylase }\end{array}$ & $\begin{array}{l}\text { PAPS } \\
\text { reductase }\end{array}$ & $\begin{array}{l}\text { Sulphite } \\
\text { reductase }\end{array}$ & $\begin{array}{l}\text { Homocysteine } \\
\text { synthase }\end{array}$ \\
\hline CC359-OL2 & - & 135 & $0 \cdot 30$ & 1.4 & 464 \\
\hline CC346-3B & met3 & - & $0 \cdot 32$ & $4 \cdot 6$ & 422 \\
\hline CC $362-2 A$ & metlo & 373 & - & $7 \cdot 4$ & 463 \\
\hline $\mathrm{C} 112$ & met 25 & 248 & 0.48 & $4 \cdot 3$ & - \\
\hline CC469-13 & met1 & 298 & 0.41 & - & 803 \\
\hline CC361-1B & met 5 & 238 & 0.41 & - & 246 \\
\hline CC496-43 & met 8 & 149 & 0.44 & - & 674 \\
\hline CC501-2 & met 10 & 255 & 0.33 & - & 382 \\
\hline CC363-20B & met 18 & 321 & $0 \cdot 31$ & - & 213 \\
\hline CC $370-8 \mathrm{C}$ & met 20 & 487 & 0.66 & - & 80 \\
\hline CC471-1D & met4 & 1.6 & - & $0 \cdot 2$ & 37 \\
\hline CC364-18C & met22 & 155 & 0.53 & $5 \cdot 6$ & 528 \\
\hline
\end{tabular}

\section{Table 5. Growth of different mutants on thiosulphate}

The growth yield data represent the maximal number of cells obtained in each experiment. Each figure represents the mean value obtained from two experiments. The deviation from this mean value was at most $20 \%$. ND, Not determined.

\begin{tabular}{|c|c|c|c|c|}
\hline \multirow[b]{2}{*}{ Strain } & \multirow[b]{2}{*}{$\begin{array}{l}\text { Relevant } \\
\text { genotype }\end{array}$} & \multirow{2}{*}{$\begin{array}{l}\text { Growth on } \\
\text { thiosulphate } \\
(0.25 \mathrm{mM})\end{array}$} & \multicolumn{2}{|c|}{$\begin{array}{c}\text { Growth yield } \\
\left(\mathrm{mg} \text { dry wt } \mathrm{ml}^{-1}\right)\end{array}$} \\
\hline & & & $\begin{array}{l}\text { Methionine } \\
(0.005 \mathrm{~mm})\end{array}$ & $\begin{array}{c}\text { Thiosulphate } \\
(0.005 \mathrm{mM})\end{array}$ \\
\hline CC359-OL2 & - & + & $0 \cdot 131$ & 0.206 \\
\hline CC $346-3 B$ & met3 & + & ND & ND \\
\hline CC $362-2 A$ & met 16 & + & ND & ND \\
\hline C112 & met 25 & - & ND & ND \\
\hline CC469-13 & metl & + & ND & ND \\
\hline CC361-1B & met5 & + & 0.093 & 0.085 \\
\hline CC496-43 & met8 & + & ND & ND \\
\hline CC501-2 & met 10 & + & $0 \cdot 115$ & 0.087 \\
\hline CC363-20B & met 18 & + & ND & ND \\
\hline CC $370-8 \mathrm{C}$ & $\operatorname{met} 20$ & + & 0.075 & 0.086 \\
\hline CC471-1D & met4 & - & ND & ND \\
\hline СC $364-18 \mathrm{C}$ & $\operatorname{met} 22$ & + & ND & ND \\
\hline
\end{tabular}

Another experiment was performed to determine if both of the sulphur atoms of thiosulphate are used by yeast. In this experiment, it was first determined that $0.005 \mathrm{~mm}$-methionine limited the growth yield of the parental strain CC359-OL2 in B medium. Then strain CC359-OL2 and met5, met 10 and met 20 mutants were grown in B medium containing $0.005 \mathrm{mM}$-methionine or $0.005 \mathrm{~mm}$-thiosulphate. Results (Table 5) show that although the growth yield of the parental strain when thiosulphate was used as a sulphur source did not reach twice that obtained when methionine was used at the same concentration, about 1.6-fold more cells were obtained on thiosulphate as compared to methionine. For the mutant strains, similar yields were obtained on the two sulphur sources and, in any case, no increase in the maximal number of cells was observed for growth on thiosulphate as compared to methionine. This is an indication that a wild-type strain uses both sulphur atoms of thiosulphate while met5, met 10 and met 20 mutants use only one.

\section{Discussion}

The results presented here show that $S$. cerevisiae can use inorganic sulphur sources such as sulphate, sulphite or thiosulphate, as well as organic sulphur sources such as homocysteine, cysteine, methionine and $S$-adenosylmethionine. S. cerevisiae has also been shown to grow on glutathione (Elskens et al., 1991).

Our evidence also indicates that the only defect of mutants met 1 and met 8 is in sulphite reductase activity. The outcome of this is that the integrity of at least five genes is required for the synthesis of an active sulphite reductase. These genes are MET1, MET5, MET8, $M E T 10$ and MET20. The nucleotide sequence of MET8 has been determined without information being gained as to its function (Cherest et al., 1990).

In $E$. coli, the subunit structure of sulphite reductase has been shown to be $\alpha_{8} \beta_{4}$. The $\alpha$ and $\beta$ subunits are encoded, respectively, by the genes cysJ and cysI (Ostrowski et al., 1989). In S. cerevisiae, the purification and characterization of sulphite reductase has led to the conclusion that the yeast enzyme is also composed of two different subunits (Yoshimoto \& Sato, 1968 a, $b, 1970$ ). In 
addition, strains no. 6, 11 and 20 from the Naiki collection were found to synthesize a modified inactive sulphite reductase (Yoshimoto \& Sato, 1968b). Strains no. 6 and 20 have been classified as met 10 mutants (Masselot \& de Robichon-Szulmajster, 1975). Moreover, cys $G$ mutants of $E$. coli have been shown to lack both nitrite reductase and sulphite reductase activities, due to an impaired synthesis of sirohaem, the prosthetic group of these two enzymes. A specific pathway allows the synthesis of the sirohaem from uroporphyrin III, and at least two enzyme-catalysed steps are needed to transform uroporphyrin III into sirohaem (Warren et al. 1990). As yeast does not possess nitrite reductase, these steps are expected to be specific for sulphite reductase in this organism. A mutation in the genes encoding the enzymes catalysing the synthesis of the sirohaem from uroporphyrin III would thus lead to methionine auxotrophic strains. It is thus reasonable to think that among the mutations resulting in the absence of sulphite reductase activity, some could be impairments in sirohaem synthesis.

The genes that encode the enzymes catalysing the different steps of the biosynthesis of sulphur amino acids are shown in Fig. 1. This model links the results presented here and other data recently published by this laboratory. The results obtained with the met 18 and the met 22 mutants still raise some questions. Mutant met 18 accumulates sulphite in vivo, showing that sulphite reductase is impaired in this mutant. The same conclusion is reached by assaying sulphite reductase in cell-free extracts. However, in vivo, the formation of sulphide from sulphite seems to be partly active in this mutant as assessed by the pale brown colour of this mutant on bismuth medium (see Fig. $2 a$ ). These observations are in favour of decreased sulphite reductase activity in vivo that is not detected in vitro due to the low sensitivity of the assay. This low sulphite reductase activity could be due to a modification in the regulation of synthesis of sulphite reductase by the met 18 mutation and is still under investigation.

The reasons for the auxotrophic requirement for organic sulphur of mutant met 22 are not well understood. The enzyme determinations show that a met 22 mutant exhibits wild-type activities of all the enzymes necessary to assimilate sulphate and yet it does not grow on sulphite or on sulphide. Although the met22 mutant does not grow on sulphite, it is able to concentrate sulphite from YPG-BIG medium as shown by the bismuth test. These observations could reveal differences in the activity or in the regulation of the transport system(s) that allow the transport of sulphate, sulphite and sulphide.

Evidence is presented that all met mutants grow on thiosulphate, with the exception of strains mutated in the MET4 and the MET25 genes. Thiosulphate metabolism in $S$. cerevisiae has not yet been studied. In Salmonella typhimurium, Nakamura et al. $(1983,1984)$ have shown that mutants defective in cysteine synthase B (encoded by the $\operatorname{cys} M$ gene) are unable to metabolize thiosulphate, whereas cys $K$ mutants devoid of cysteine synthase A can use this metabolite. These authors have shown, moreover, that cysteine synthase B has a sulphocysteine synthase activity in vitro that catalyses the formation of $S$-sulphocysteine from $O$-acetylserine and thiosulphate. The pathway for thiosulphate utilization in Salmonella typhimurium would thus be: thiosulphate $\rightarrow S$-sulphocysteine $\rightarrow$ cysteine (Kredich, 1987). It should be stressed that this pathway is used when thiosulphate is present as a sulphur source and that this sulphur component is not an obligatory intermediate in sulphate assimilation. This is not the case in the genus Streptomyces, in which it has been proposed that thiosulphate could be an intermediate in the sulphate assimilation pathway (Kitano et al., 1985; Lydiate et al. 1988). In $S$. cerevisiae, the results presented above show that the wild-type strain uses the two sulphur atoms of thiosulphate and that mutants impaired in sulphite reductase activity are capable of using only one sulphur atom of thiosulphate, showing that the utilization of one sulphur atom of thiosulphate involves sulphite reductase. The utilization of the other sulphur atom leads to the formation of sulphide, as assessed by the colour of all met mutants when tested on bismuth medium, where formation of sulphide from thiosulphate yields coloured cells. The mechanism of thiosulphate cleavage could involve thiosulphate reductase, which has been purified from yeast (Chauncey \& Westley, 1983). Indeed, this enzyme has been shown to cleave thiosulphate yielding sulphite and also sulphide, which can be used by all mutants impaired only in sulphate reduction. This observation explains the inability of the met 25 mutant to use thiosulphate, as it is unable to use sulphite or sulphide. The MET4 gene encodes the transcriptional activator of all genes implicated in sulphate reduction and sulphur incorporation: a strain bearing a mutation in this gene cannot grow on sulphite or sulphide and consequently cannot use thiosulphate either.

\section{References}

Chauncey, T. R. \& Westley, J. (1983). Improved purification and sulfhydryl analysis of thiosulfate reductase. Biochimica et Biophysica Acta 744, 304-311.

Cherest, H., Nguyen Ngoc, T. \& Surdin-Kerjan, Y. (1985). Transcriptional regulation of the met 3 gene of Saccharomyces cerevisiae. Gene 34, 269-281.

Cherest, H. \& Surdin-KerJan, Y. (1992). Genetic analysis of a new mutation conferring cysteine auxotrophy in Saccharomyces cerevisiae: updating of the sulfur metabolism pathway. Genetics $\mathbf{1 3 0}$, 51-58. 
Cherest, H., Kerjan, P. \& Surdin-Kerjan, Y. (1987). The Saccharomyces cerevisiae MET3 gene: nucleotide sequence and relationship of the $5^{\prime}$ non-coding region to that of MET25. Molecular and General Genetics 210, 307-313.

Cherest, H., Thomas, D. \& Surdin-Kerjan, Y. (1990). Nucleotide sequence of the MET8 gene of Saccharomyces cerevisiae. Nucleic Acids Research 18, 659.

Cohen, G. N. \& SAINT GIRons, I. (1987). Biosynthesis of threonine, lysine, and methionine. In Escherichia coli and Salmonella typhimurium: Cellular and Molecular Biology, pp. 429-444. Edited by F. C. Niedhardt and others. Washington, DC: American Society for Microbiology.

Elskens, M. T., Jaspers, C. L. \& Penninckx, M. J. (1991). Glutathione as an endogenous sulphur source in the yeast Saccharomyces cerevisiae. Journal of General Microbiology 137, 637-644.

Grant, W. M. (1947). Colorimetric determination of sulfur dioxide. Analytical Chemistry 19, 345-346.

Kerjan, P., Cherest, H. \& Surdin-Kerjan, Y. (1986). Nucleotide sequence of the Saccharomyces cerevisiae MET25 gene. Nucleic Acids Research 14, 7861-7871

Kitano, K., NozaKi, Y. \& Imada, A. (1985). Selective accumulation of unsulfated carbapenem antibiotics by sulfate transport-negative mutants of $S$. griseus subsp. cryophilus C-19393. Agricultural and Biological Chemistry 49, 677-684.

Korch, C., Mountain, H. A. \& Bystrom, A. S. (1991). Cloning, nucleotide sequence and regulation of MET14, the gene encoding the APS kinase of Saccharomyces cerevisiae. Molecular and General Genetics 228, 96-108.

KREDICH, N. H. (1987). Biosynthesis of cysteine. In Escherichia coli and Salmonella typhymurium: Cellular and Molecular Biology, pp. 419428. Edited by F. C. Niedhardt and others. Washington, DC: American Society for Microbiology.

LydiATE, D. J., MENDEZ, C., KieSER, H. M. \& HoPWOOD, D. A. (1988). Mutation and cloning of clustered Streptomyces genes essential for sulphate metabolism. Molecular and General Genetics 211, 415-423.

Masselot, M. \& De Robichon-Szulmajster, H. (1975). Methionine biosynthesis in Saccharomyces cerevisiae. I. Genetical analysis of auxotrophic mutants. Molecular and General Genetics 139, 121-132.

Masselot, M. \& SuRdin-KerJan, Y. (1977). Methionine biosynthesis in Saccharomyces cerevisiae. II. Gene-enzyme relationships in the sulfate assimilation pathway. Molecular and General Genetics 154 23-30.

NaKamura, T., Kon, Y., Iwahashi, H. \& Eguchi, Y. (1983). Evidence that thiosulfate assimilation by Salmonella typhimurium is catalysed by cysteine synthase B. Journal of Bacteriology 156, 656-662.

NaKamuRa, T., IWAHASHI, H. \& EGUCHI, Y. (1984). Enzymatic proof for the identity of the S-sulfocysteine synthase and cysteine synthase B of Salmonella typhimurium. Journal of Bacteriology 158, 11221127.
Ostrowski, J., Wu, J.-Y., Rueger, D. C., Miller, B. E., Siegel, K. M. \& KREDICH, N. M. (1989). Characterization of the cysJIH regions of Salmonella typhimurium and Escherichia coli B. DNA sequences of $c y s I$ and $c y s H$ and a model for the siroheme-- $\mathrm{Fe}_{4} \mathrm{~S}_{4}$ active center of sulfite reductase hemoprotein based on amino acid homology with spinach nitrite reductase. Journal of Biological Chemistry 264, 15726-15737.

Rikkerink, E. H. A., Magee, B. B. \& Magee, P. T. (1988). Opaque-white phenotype transition: a programmed morphological transition in Candida albicans. Journal of Bacteriology 170, 895-899.

Schwenn, J. D., Krone, F. A. \& Husmann, K. (1988). Yeast PAPS reductase: properties and requirements of the purified enzyme. Archives of Microbiology 150, 313-319.

SIEGEL, L. M. (1965). A direct microdetermination for sulfide. Analytical Biochemistry 11, 126-132.

Thomas, D., Cherest, H. \& Surdin-Kerjan, Y. (1989). Elements involved in $S$-adenosylmethionine mediated regulation of the Saccharomyces cerevisiae MET25 gene. Molecular and Cellular Biology 9, 3292-3298.

Thomas, D., BARBey, R. \& Surdin-KerJan, Y. (1990). Gene-enzyme relationship in the sulfate assimilation pathway of Saccharomyces cerevisiae. Journal of Biological Chemistry 265, 15518-15524.

Thomas, D., Cherest, H. \& Surdin-KerJan, Y. (1991). Identification of the structural gene for glucose-6-phosphate dehydrogenase in yeast. Inactivation leads to nutritional requirement for inorganic sulfur. EMBO Journal 10, 547-553.

Thomas, D., JACQUemin, I. \& SURdin-KeRJAN, Y. (1992). MET4, a leucine zipper protein, and centromere binding factor 1 are both required for transcriptional activation of sulfur metabolism in yeast. Molecular and Cellular Biology 12, 1719-1727.

TSANG, M. L.-S. \& SchifF, J. A. (1976). Sulfate reducing pathway in Escherichia coli involving bound intermediates. Journal of Bacteriology 125, 923-933.

DE VITO, P. C. \& DREYFuss, J. (1964). Metabolic regulation of adenosine triphosphate sulfurylase in yeast. Journal of Bacteriology 88, 1341-1348.

WARREN, M. J., RoEssner, C. A., SANTANDER, P. J. \& SCOTt, I. (1990). The Escherichia coli cysG gene encodes $S$-adenosylmethioninedependent uroporphyrinogen III methylase. Biochemical Journal 265, 725-729.

Yoshimoto, A. \& SATO, R. (1968a). Studies on yeast sulfite reductase. I. Purification and characterization. Biochimica et Biophysica Acta 153, 555-575.

Yoshimoto, A. \& SATo, R. (1968b). Studies on yeast sulfite reductase. II. Partial purification and properties of genetically incomplete sulfite reductases. Biochimica et Biophysica Acta 153, 576-588.

Yoshimoto, A. \& Sato, R. (1970). Studies on yeast sulfite reductase. III. Further characterization. Biochimica et Biophysica Acta 220, 190205. 